\title{
To the nucleolar density and size in apoptotic human leukemic myeloblasts produced in vitro by Trichostatin A
}

\author{
K. Smetana, ${ }^{1}$ M. Zápotocký, ${ }^{2}$ J. Starková, ${ }^{2}$ J. Trka ${ }^{2}$ \\ ${ }^{1}$ Institute of Haematology and Blood Transfusion, Prague; ${ }^{2}$ Department of Paediatric Haematology and \\ Oncology, $2^{\text {nd }}$ Medical School of Charles University, Prague, Czech Republic
}

ili

(C)2008 European Journal of Histochemistry

The present study was designed to provide more information on nucleoli in apoptotic cells, which were represented in the present study by cultured leukemic myeloblasts (Kasumi-1 cells). The apoptotic process in these cells was produced by trichostatin A (TSA) that is a histone deacetylase inhibitor with strong cytostatic effects. The selected TSA concentration added to cultures facilitated to study apoptotic and notapoptotic cells in one and the same specimen. The nucleolar diameter and density were determined using computer assisted measurement and densitometry in specimens stained for RNA. In comparison with not-apoptotic cells, in apoptotic cells, nucleolar mean diameter did not change significantly and nucleolar RNA density was also not apparently different. On the other hand, the cytoplasmic RNA density in apoptotic cells was markedly reduced. Thus it seemed to be possible that the transcribed RNA remained "frozen" within the nucleolus but its transport to the cytoplasm decreased or stopped. However, the possibility of the RNA degradation in the cytoplasm of apoptotic cells based on the present study cannot be eliminated. At this occasion it should be added that AgNORs reflecting nucleolar biosynthetic and cell proliferation activity in apoptotic cells decreased in number or disappeared. The presented results also indicated that large nucleoli intensely stained for RNA need not be necessarily related to the high nucleolar biosynthetic or cell proliferation activity and may be also present in apoptotic cells responding to the cytostatic treatment.

Key words: apoptotic cells, nucleolar density, nucleolar diameter.

Correspondence: Karel Smetana,

Institute of Hematology and Blood Transfusion,

U nemocnice 1, Prague 2, Czech Republic, 12820

Tel.: +420.2.21977271.

Fax: +420.2.21977249.

E-mail: karel.smetana@uhkt.cz

Paper accepted on June 16, 2008

European Journal of Histochemistry

2008; vol. 52 issue 3 (July-September): 143-148
$\mathrm{N}$ ucleolar changes in apoptotic cells and apoptotic bodies were less studied although nucleolar morphology is a very useful tool and marker for the evaluation of various cell states at the single cell level (Busch and Smetana 1970; Wachtler and Stahl, 1993). According to previous studies various cells in pre-apoptotic or apoptotic state may contain nucleoli with altered structure and size, which, together with other RNP components may by even expulsed out from the nucleus (Biggiogera et al., 2004; Martelli et al., 2001; Pellicciari et al., 2000; Smetana, 2002). On the other hand, only few reports are dealing with the nucleolar size and RNA density when the apoptotic process was induced by a cytostatic treatment without preceding terminal maturation (Smetana, 2004). Thus the present study was undertaken to provide more information on the density of nucleolar bodies in apoptotic leukemic myeloblasts in which the apoptotic process was induced by a histone deacetylase inhibitor represented by trichostatin A (TSA). The cytostatic and apoptotic effect of that drug on some malignant cells is known and represents a subject of a great interest and discussions concerning the pathway of action (Choi, 2005; Smetana et al., 2007b; Wu et al., 2007; Yamashita et al., 2003). Kasumi-1 cells originated from acute myeloid leukaemia (type M2 according to FAB classification) and represented leukemic myeloblasts in the present study. These myeloblasts are a very convenient model for $A M L$ in vitro and do not lose an ability to differentiate (Asou et al., 1999; Larizza et al., 2005). In addition, the selected concentration of TSA added to cultures of these cells facilitated to study not-apoptotic and apoptotic myeloblasts in one and the same specimen (Smetana et al., 2007a). 


\section{Materials and Methods}

Kasumi-1 cell line originating from human acute myeloid leukaemia - type M2 according to FAB classification (see DSMZ, 2004; LGC Promochem, 2006) was received as a generous gift from Dr. 0. Krejčí (Massachutsetts General Hospital Cancer Center, Boston, USA). Leukemic myeloblasts were cultured in RPMI 1640 medium with $20 \%$ foetal bovine serum (Gibko, USA) at $37^{\circ} \mathrm{C}$ in an atmosphere containing 5\% carbon dioxide (see LGC Promochem, 2006). Aliquots were cultured without or with TSA (Sigma Aldrich, USA) at concentration $120 \mathrm{~nm}$ for $24 \mathrm{~h}$. Under these conditions, mitotic divisions in TSA treated cells disappeared and the number of apoptotic cells significantly increased (see Smetana et al., 2007a,b). Cytospins of cultured leukemic myeloblasts were prepared by centrifugation at $800 \mathrm{r} / \mathrm{min}$ for 5 min using a Universal 16 R centrifuge, rotor 1624 (Hettich, Germany).

Dry cytospins not older than $24 \mathrm{~h}$ were stained without fixation for RNA by $0.05 \%$ acidified methylene blue at pH 5.3 (Smetana et al., 1969; Ochs 1998). Silver stained proteins of AgNORs were visualised by silver reaction on dry unfixed cytospins older than 6 days. Then cytospins were incubated in silver reagent for $5-10 \mathrm{~min}$ at $37^{\circ} \mathrm{C}$ in the dark. The silver reagent consisted of 2 parts of $50 \%$ silver nitrate and 1 part of colloidal developer containing $2 \%$ gelatine in $1 \%$ formic acid (Howell and Black, 1980; Ploton et al., 1986). The incidence of apoptotic cells and bodies was evaluated in methanol fixed cytospins stained for DNA by acidified methylene blue for $10 \mathrm{~min}$ after hydrolysis with $1 \mathrm{~N} \mathrm{HCl}$ at $60^{\circ} \mathrm{C}$ for $10 \mathrm{~min}$ (Busch and Smetana, 1970; Smetana et al., 2000).

Micrographs were taken with a Camedia digital photo camera C40C40 Z00M (Olympus, Japan) placed on Jenalumar microscope (Zeiss, Germany). The captured images were processed with Quick Photoprogam (Olympus, Japan) in combination with Infanview (Irfan Skiljan, Austria) and Power Point Microsoft (USA) programs. Mean nucleolar diameters of each nucleolar body without perinucleolar chromatin were measured at magnification $4300 x$ on the screen using Quick Photoprogram. Then these measured diameters were used for calculation of mean nucleolar diameter for each evaluated cell (see e.g. Smetana et al., 2007a). The nucleolar and cytoplasmic density was measured on specimens stained for RNA using National
Institutes of Health Image Program - Scion for Windows (Scion Corp., USA) after image conversion of captured colour images to grey scale. The measured density was expressed in arbitrary units calculated by subtracting measured nucleolar and cytoplasmic density from the background surrounding each measured cell (Figures 1 and 2). Such calculation eliminated artificial density due to the background density produced by the specimen preparation for microscopy.

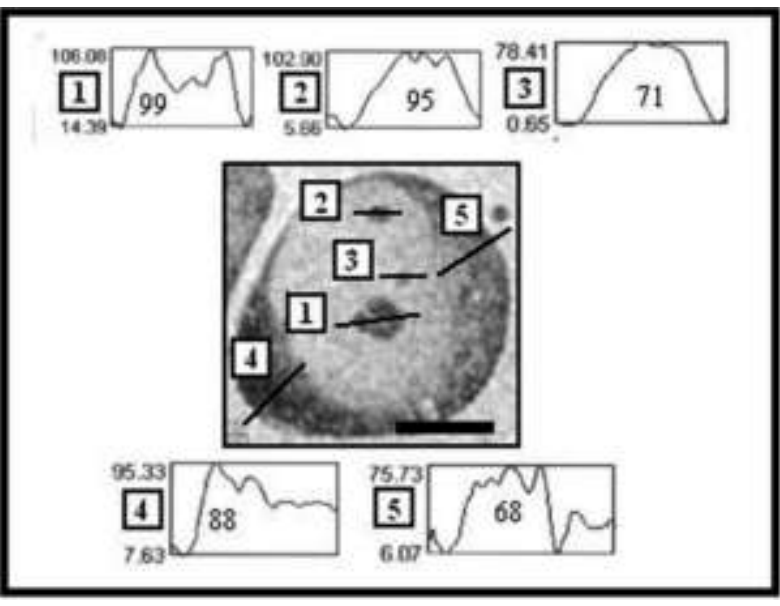

Figure 1. A TCA untreated cell. Numbers in the Figure correspond to densitographs. Numbers within densitographs represent arbitrary density units. Mean nucleolar density $/$ cell = 88.3 \pm 10.7 , mean cytoplasmic density $/$ cell $=78.0 \pm 7.0$. Black lines indicate measurement lines. The black thick bar in this and following figures represents 5 $\mathrm{m}$.

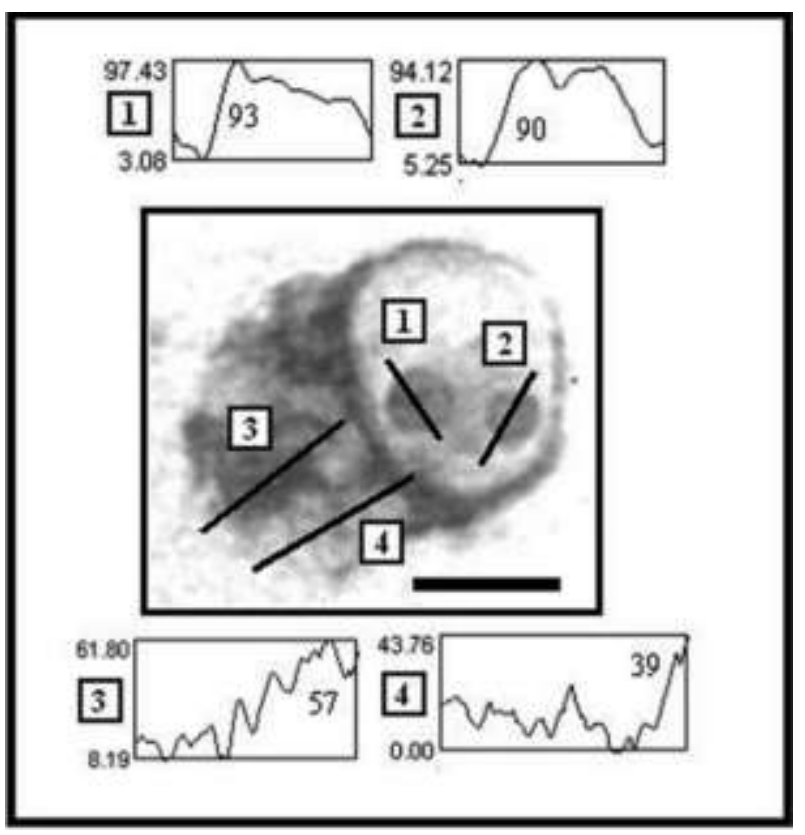

Figure 2. A TCA treated apoptotic cell. Nucleolar density = $91.5 \pm 1.2$, cytoplasmic density $=48.0 \pm 7.3$. For legend see Figure 1. 


\section{Results}

In untreated control cultures the number of apoptotic cells was very small and practically did not reach $5 \%$. In contrast, in TSA treated cultures the percentage of apoptotic cells or bodies with a characteristic appearance was large enough $(51 \pm 6$ per cent) and facilitated to study nucleoli in both apoptotic cells and bodies and less sensitive or resistant cells, i.e. in not-apoptotic cells (see also Smetana et al., 2007b). In addition, no signs of cell differentiation were noted in both TSA untreated and treated cultures.

In untreated control cells, nucleoli were characterized by numerous AgNORs representing fibrillar centres in the electron microscope (Figure 3, ref. Smetana, 2002; Wachtler and Stahl, 1993). In treated but not-apoptotic cells, nucleoli appeared similar. However, in some of them, enlarged AgNORs were apparently reduced in number and occasionally translocated to the nucleolar periphery (Figure 4). Such decrease and translocation of AgNORs indicated a reduced nucleolar biosynthetic activities and/or premature ageing (Derenzini, 2000; Smetana et al., 2006). Apoptotic cells and bodies also possessed a reduced number of AgNORs, which occasionally disappeared (Figure 5).

After staining for RNA, nucleoli in untreated cells appeared as relatively uniform bodies, which, however, possessed less stained small areas corresponding to fibrillar centres. Such small areas were more apparent in not-apoptotic cells cultured with TSA (Figure 6). The mean density of nucleoli was similar in both TSA untreated or treated not-apoptotic and apoptotic cells (Figures 1 and 2, Table 1 ). However, the variability of measured values in individual treated cells was large and the variability coefficient was about 25 per cent for not-apoptotic and 15 per cent for apoptotic cells (see also the

Table 1. The nucleolar size, nucleolar and cytoplasmic RNA density. ${ }^{\S}$

\begin{tabular}{lcccc}
\hline Cells & \multicolumn{2}{c}{ RNA density } & No/Cy & Dia \\
& No & Cy & RNA density & $(\mu \mathrm{m})$ \\
\hline TSA untreated & $98.3 \pm 8.1^{*}$ & $69.3 \pm 7.3$ & $1.3 \pm 0.1$ & $2.5 \pm 0.4$ \\
TSA treated not-apo & $102.8 \pm 26.3$ & $76.4 \pm 30.0$ & $1.3 \pm 0.5$ & $2.3 \pm 0.4$ \\
apo & $97.9 \pm 15.9$ & $55.2 \pm 25.9^{*}$ & $1.9 \pm 0.6^{*}$ & $2.2 \pm 0.3$ \\
\hline
\end{tabular}

sbased on 300 measurements; "mean and standard deviation; *significantly different from untreated and treated not-apoptotic cells using $t$-test $(p<0.02)$

No, Nucleoli; Cy, Cytoplasm; Dia, mean nucleolar diameter per cell; not-apo, not-apoptotic cells; apo, apoptotic cells.

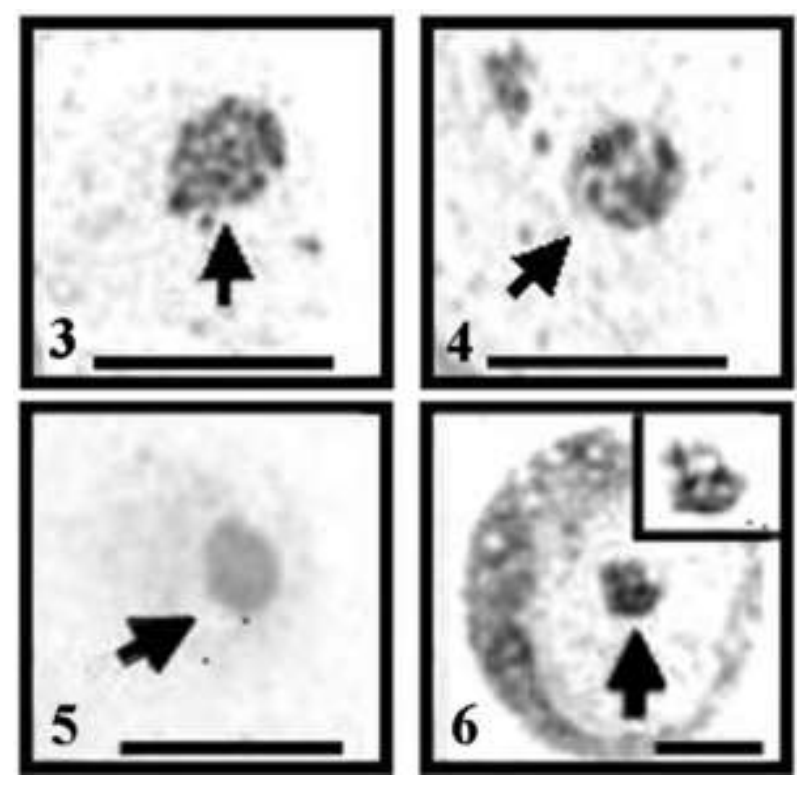

Figure 3. Numerous AgNORs (arrow) in a TCA untreated cell. Figure 4. In comparison with untreated cells (see Figure 3 ), the TCA treated cell contains a reduced number of enlarged AgNORs in the larger nucleolus (thick arrow).

Figure 5. The absence of AgNORs (arrow) in an apoptotic body. Figure 6. A TCA treated not-apoptotic cell containing a nucleolus (arrow) with light areas, which appeared more distinct in the insert after enlargement and high contrast printing.

standard deviation, Table 1). In contrast, the cytoplasmic density in apoptotic cells or bodies was significantly smaller than in TSA untreated or treated but not-apoptotic cells (Figures 1 and 2, Table 1). Such decrease of the cytoplasmic density in apoptotic TSA treated cells was reflected by the significantly increased of nucleolar to cytoplasmic density ratio of apoptotic cells and bodies (Table 1 ). At this occasion it should be noted that the variability of measured values of the cytoplasmic RNA density was also large in both treated not-apoptotic and apoptotic cells or bodies. In addition, the RNA density within the cytoplasm of apoptotic cells exhibited a large variability due to less or more stained areas (Figure 2). The variability coefficient calculated for mean cytoplasmic RNA density was much higher in both groups treated not-apoptotic (about $30 \%$ ) and apoptotic cells (about $25 \%$ ) in comparison with untreated ones (about $8 \%$ ).

The nucleolar mean diameter in specimens stained for RNA appeared to be only slightly decreased in TCA treated not-apoptotic and apoptotic cells or bodies. However, in comparison with TCA untreated cells, the slightly decreased nucleolar size in not-apoptotic and apoptotic cells or bodies was not significantly different (Table 1 ). 


\section{Discussion}

The present study demonstrated that the nucleolar RNA density in not-apoptotic and apoptotic cells was similar in contrast to the cytoplasmic one. On the other hand, the nucleolar biosynthetic or cell proliferation activities of apoptotic cells or bodies were apparently reduced and abolished demonstrated by the decreased number of AgNORs (Derenzini, 2000; Giuffrè et al., 2006; Morimoto et al., 2001; Smetana et al., 2004). Thus it seems to possible that the transcribed RNA remained frozen within the nucleolus but its transport to the cytoplasm might decrease or stop. Such explanation is also supported by the markedly decreased cytoplasmic RNA density, which was reflected by the increased nucleolar to cytoplasmic RNA density ratio. However, the previously reported degradation of cytoplasmic RNA in altered or apoptotic cells (Delic et al., 1993) on the base of the present study also cannot be eliminated and the variability of the RNA density within the cytoplasm does not contradict such possibility In contrast, the release of RNA at the surface of apoptotic cells (Biggiogera et al., 1998) was not observed because of the absence of an increased RNA density at the cell periphery.

According to presented results in apoptotic cells or bodies without decreased nucleolar RNA density, the nucleolar mean diameter was also not substantially influenced. Thus in contrast to naturally occurring apoptosis or other morphological expression of the apoptotic process (see Biggiogera et al., 1998; 2004; Martelli et al., 2001; Pellicciari et al., 2000; Smetana, 2002), the apoptotic process induced by a strong cytostatic agent in the present study did not influence both the nucleolar RNA density and size. The similar nucleolar RNA density in both notapoptotic and apoptotic cells was also noted after photodynamic treatment but the cytoplasmic RNA density was not measured at that time (Smetana et al., 2004). Therefore, large nucleoli intensely stained for RNA need not be necessarily related to the nucleolar large biosynthetic or cell proliferation activity and may be also present in apoptotic cells responding to the cytostatic treatment. At this occasion it should be mentioned that AgNORs were reduced in number and/or absent after TSA treatment. Moreover, mitotic cells in TSA treated cultures were not present and the incidence of mitotic cells was generally considered as a tool for the evaluation of anti-tumour agents (Ikeda et al., 2000).

\section{Acknowledgements}

This study was supported in part by the Czech Ministry of Health - Research Project VZ 0002373601 and Research Grant of the Charles University 71/2006. The authors would like to express their gratitude to Mrs. Jirásková for technical assistance and Dr. O. Krejci for kind assistance in the preparation of the manuscript.

\section{References}

Asou H, Tashiro S, Hamamoto K, Otsui A, Kita K, Kamada N. Establishment of a human acute myeloid cell line (Kasumi-1) with B:21 chromosome translocation. Blood 1991; 77:2031-6.

Busch H, Smetana K. The nucleolus. Academic Press, New York, 1970.

Biggiogera M, Bottone MG, Pellicciari C. Nuclear RNA is extruded from apoptotic cells. J Histochem Cytochem 1998;46:999-1005.

Biggiogera M, Bottone MG, Scovassi AI, Soldani C, Vecchio L, Pellicciari C. Rearrangement of nuclear ribonucleoprotein (RNP)containing structures during apoptosis and transcriptional areas. Biol Cell 204; 603:603-15.

Choi $\mathrm{YH}$. Induction of apoptosis by trichostatin A, a histone deacetylase inhibitor, is associated with inhibition of cyclooxygenase-2 activity in human non-small cell lung cancer cells. Int $\mathrm{J}$ Oncol 2005;27:473-9.

Delic J, Coppey Moisant M, Magdalenat H. Gamma-ray-induced transcription and apoptosis-associated loss of 28S RNA in interphase human lymphocytes. Int J Rad Biol 1993;64:39-46.

Derenzini M. The AgNORs. Micron 2000;31:117-20.

DSMZ (Deutsche Sammlung von Mikroorganismen und Zellkulturen), Human and animal cell lines, Kasumi-1, ACC 220, 2004.

Giuffrè G, Mormandi F, Barresi V, Bordi C, Tuccari G, Barresi G. Quantity of AgNORs in gastric endocrine carcinoid fumours as a potential prognostic tool. Eur J Histochem 2006;50:45-50.

Howell WM, Black DA. Controlled silver-staining of nucleolus organizer regions un human leukemic cells with a protective colloidal developer: a 1 step method. Experientia1980;36:1014-5.

Ikeda K, Pant B, Mishiro A, Ozawa K, Masujima T. Sugiyama M. A convenient method for the evaluation of anti-tumor agents affecting the cell cycle. J Biolsci Bioeng 2000;90:574-6.

Larizza I, Magnani I, Beghini I. The Kasumi-1 cell line: a t(8;21)- kit mutant model for acute myeloid leukaemia. Leukoc Lymphoma 2005; 46:247-55.

LGC Promochem, Catalogue, American Tissue Cell Cultures, Catalogue, Kasumi-1, CRL 2724, 2006.

Martelli AM, Zweyer M, Ochs RL, Tazzari PL, Tabellini G, Narducci P, Bortul R. Nucleolar apoptotic changes: An overview, J Cell Biochem 2001;82:634-46.

Morimoto $\mathrm{Y}$, Kito S, Ohba T, Morimoto M, Okamura H, Haneji T. Alteration of argyrophilic nucleolus organizer region associated proteins (AgNOR) proteins in apoptosis-induced human salivary gland cells and human oral squamous carcinoma cells. J Oral Pathol Med 2001;30:193-9.

Ochs RL. Methods used to study structure and function of the nucleolus. Methods Cell Biol 1998;53:303-21.

Pellicciari C, Bottone MG, Scovassi AI, Martin TE, Biggiogera M. Rearrangement of nuclear ribonucloproteins and extrusion of nucleolus-like bodies during apoptosis induced by hypertonic stress. Eur $\mathrm{J}$ Histochem 2000;44:247-54.

Ploton D, Ménager M, Jeanneson P, Himber G, Pigeon F, Adnet JJ. Improvement in the staining and in the visualization of the argyrophilic proteins in the nucleolus organizer region at the optical level. Histochem J 1986;18:5-14.

Smetana K. Structural features in blood, leukemic, lymphoma and myeloma cells. Eur J Histochem 2002;46:125-32.

Smetana K, Cajthamlová H, Grebeňová D, Hrkal Z. The 5-aminolaevulinic acid based-photodynamic effects on nucleoli and nuclei of 
HL-60 leukemic granulocytic precursors. J Photochem Photobiol B 2000;59:80-6.

Smetana K, Chan PK, Marinov Y, Souček J, Hrkal Z, Busch H. A short note on the nucleolar density in apoptotic leukemic granulocytic precursors (HL-60 cells). Life Sci 2004;75:791-6.

Smetana K, Klamová H, Pluskalová M, Stöckbauer P, Hrkal Z. To the intranucleolar translocation of AgNORs in leukemic early granulocytic and plasmacytic precursors. Histochem Cell Biol 2006; 125:165-70,

Smetana K, Kuželová K, M. Zápotocký M, Starková J, Hrkal Z, Trka J. Mean diameter of nucleolar bodies in cultured human leukemic myeloblasts is related to $\mathrm{S}$ and G2 phase of the cell cycle. Europ J Histochem 2007a;51:269-74.

Smetana K, Lejnar J, Potmesil M. A further contribution to the demonstration of RNA and nucleoli in smear preparations. Folia Haematol
1969;91:381-4.

Smetana K, Zápotocký M, Starkova J, Trka J. Effect of histone deacetylase inhibitors on the cell nucleus and nucleolus of leukemic myeloblasts in vitro - A cytochemical study. Acta histochem 2007b; 109:413-9.

Wachtler F, Stahl A. The nucleolus: A structural and functional interpretation. Micron 1993;24:473-505.

Wu ZQ, Zhang R, Chao C, Zhang JF, Zhang YQ. Histone deacetylase inhibitor trichostatin $\mathrm{A}$ induced caspase-independent apoptosis in human gastric cancer cell. Chin Med J (Engl) 2007;120:2112-8.

Yamashita Y, Shimanda M, Harimoto N, Rikimaru T, Shirabe K, Tanaka $\mathrm{S}$ et al. Histone deacetylase inhibitor trichostatin A induces cell cycle arrest/apoptosis and hepatocyte differentiation in human hepatoma cells. Int J Cancer 2003;103:572-6. 
K. Smetana et al. 